\title{
Społeczno-kulturowa wartość wykorzystania gier i zabaw w edukacji, integracji międzypokoleniowej i międzykulturowej według koncepcji Edmunda Bojanowskiego
}

\begin{abstract}
Gy i zabawy stanowią jedno z ważnych osiągnięć kulturowych cywilizacji $\checkmark$ ludzkiej od najdawniejszych czasów jej istnienia. Ich bogactwo i różnorodność cieszy się zainteresowaniem i znajduje praktyczne zastosowanie w aktywności dzieci, młodzieży oraz osób dorosłych. Wykorzystywane są w rozwoju i nauce dzieci, dając możliwość twórczej aktywności, w spędzaniu czasu wolnego i odpoczynku, a także w tworzeniu więzi społecznych i kulturowych. Dlatego gry i zabawy stanowią przedmiot badań zarówno w wymiarze teoretycznym, jak i praktycznym. Analizy podejmowane są na kolejnych etapach dziejów ludzkości w różnych kontekstach historycznych, pojawiających się problemach i potrzebach społecznych, adekwatnie do rozwoju nauki, nasilenia inicjatyw społecznych i potrzeb aplikacyjnych dorobku w tej dziedzinie. Na społeczno-kulturowy walor gier i zabaw oraz ich wykorzystanie dla ochrony osoby, rodziny i wartości narodowych przez edukację i integrację społeczną, zwracał uwagę Edmund Bojanowski.

Istnieje obecnie potrzeba opracowania podstaw teoretycznych dla aplikacji zasobów dziedzictwa kulturowego, w tym gier i zabaw, oraz włączenia ich w praktykę edukacyjną i kulturalną. Jest to ważne dla właściwego wykorzystania zebranych i opracowanych przez Bojanowskiego wskazań dla pedagogów, animatorów kultury, misjonarzy oraz placówek edukacyjnych, realizujących
\end{abstract}

S. DR HAB. MARIA OPIELA, PROF. KUL - Katolicki Uniwersytet Lubelski Jana Pawła II, Katedra Historii Wychowania, Opieki i Pedagogiki Społecznej, Wydział Nauk Społecznych, e-mail: sloyola@ wp.pl, ORCID: 0000-0002-0077-8985. 
jego koncepcję w różnych częściach świata. Chodzi o jej kontynuację, a w aktualizacji - o uwzględnienie uwarunkowań i potrzeb osób w danym miejscu i czasie jej realizacji. Przygotowano w tym celu projekt aplikacji dorobku myśli i praktyki pedagogicznej Bojanowskiego na rzecz innowacji w edukacji i integracji międzypokoleniowej. Uwzględnia on zastosowanie gier i zabaw dla przekazu i urzeczywistniania wartości w integralnym rozwoju człowieka, w wielorakich relacjach osobowych i kulturowych.

\section{Gry i zabawy jako element kultury dawnej i współczesnej}

Analizę kulturowego wymiaru i znaczenia zabawy podjął Johan Huizinga, wykazując, że jest to specyficzna jakość działania starsza od kultury ludzkiej, przenikająca ją od samego początku i wciąż jej towarzysząca'. Pojęcie zabawy określa się jako zachowanie utożsamiane z grą, stąd ważne jest wskazanie, iż "grę można uznać za dynamiczną, wewnętrzną strukturę większości zabaw, gdyż gra dotyczy również zabaw z udziałem wyobraźni, czyli kreacji fikcyjnego świata „na niby” (...). W ujęciu psychologii grom i zabawom przypisuje się walor działan autotelicznych (bezinteresownych), ekspresywnych, „cel sam w sobie" (J. Piaget, J. Huizinga), a zarazem cele poznawcze, aspekty twórcze, projektowanie pożądanego świata"2.

Każda gra jest zatem zabawą, lecz nie każda zabawa jest grą, która jest odmianą zabawy, polegającą na respektowaniu ściśle ustalonych reguł, ucząc i przyzwyczajając do ich przestrzegania. Gry i zabawy są zróżnicowane społecznie i historycznie. Jako takie kreują rzeczywistość fikcyjną, a zarazem modelują realną praktykę życiową uczestników³. Pełnią więc funkcję kulturotwórczą, ucząc relacji międzyludzkich i utrwalając wzory społecznie akceptowanych zachowań.

Charakterystyki zabawy dokonał T. Paleczny, uznając że „jest zjawiskiem społecznym i kulturowym o powszechnym i uniwersalnym zasięgu i zakresie. Towarzyszyła zbiorowościom ludzkim w każdej fazie organizacji życia społecznego, pełniąc niezmiennie te same funkcje. Integrowała, ale służyła także podtrzymywaniu wzorów organizacji i hierarchizacji społecznej. Miała wymiar sakralny i świecki. Obejmowała zarówno uczestników, jak i rekwizyty, scenariusze, przepisy zabawy, rozwijającej się w różnych kulturach w różnorodnych formach tanecznych, sportowych grach, imprezach zbiorowych. Zabawa zawsze

${ }^{1}$ J. Huizinga, Homo ludens. Zabawa jako źródło kultury, Warszawa 1985, s. 21-22.

${ }^{2}$ Zabawa, w: Encyklopedia PWN, online: https://encyklopedia.pwn.pl/haslo/zabawa;3999635. html [dostęp: 22 kwietnia 2020].

3 Tamże. 
towarzyszyła życiu zbiorowemu, była i pozostała atrybutem i elementem życia społecznego. [...] Z natury rzeczy zabawa jest zjawiskiem grupowym"4.

Zabawa więc uczy i ustanawia rodzaj kontaktów między ludźmi, rozwija potrzebę wspólnego działania i przeżywania 5 .

Kontekst społeczno-kulturowy wskazuje na walor aplikacyjny gier i zabaw w edukacji, integracji międzypokoleniowej i międzykulturowej. Wraz z postępującymi przemianami cywilizacyjnymi dokonywały się przemiany wzorów zachowań i wytworów kultury wyrażających tożsamość danej społeczności. Jest wiele aspektów ich kontynuacji, w których od zarania ludzkiej kultury nic się nie zmieniło. Jak dawniej, tak i dziś ludzi łączy przede wszystkim wspólna natura ludzka, wspólne potrzeby - zwłaszcza podstawowe, a różni rozmaitość sposobów ich zaspokajania, odmienne wzory kulturowe w sposobie zachowania i myślenia. Badacze wskazują, iż „z punktu widzenia analizy zabawy jako fenomenu kultury zasady zabawy nie zmieniły się, zmieniła się jedynie forma, a niekiedy treśc" ${ }^{\prime}$. Zmieniają się one wraz z rozwojem nauki, techniki, nowych technologii i środków masowego przekazu oraz procesami globalizacyjnymi, zwiększającymi wielokulturowość świata i różnorodność przejawów międzykulturowości.

$\mathrm{Na}$ ten wątek zwracał uwagę Bojanowski odnosząc się do zabaw dzieci: „W malutkich sprawach dziecięcych odkrywa się często wątek rozległych następstw wiążący się z najżywotniejszymi zagadnieniami społecznymi. [...] Nieraz w pospolitej zabawie dziecięcej odkrywa się tajemniczy wątek, który prawie niedojrzaną związką bywa cudnie spięty z najżywotniejszą stroną narodowego jestestwa"7. Zabawa zarówno dzieci, jak i dorosłych jako fenomen kultury jest nadal sposobem i płaszczyzną skutecznego międzypokoleniowego i międzykulturowego przekazu wzorców oraz wzajemnej wymiany wartości.

Przemiany cywilizacyjne stawiają wyzwania dla poszczególnych osób i społeczeństw, co wymaga umiejętności rozumienia świata społecznego i nieustannego poznawania go na nowo, wprowadzania człowieka także poza obręb jego środowiskowych uwarunkowań, przeżyć i doświadczeń. Jest to zadaniem edukacji, która pozwala na wzbogacenie dotychczasowych form widzenia świata i pomaga prowadzić do uznania odmienności kulturowych ${ }^{8}$. Wykorzystanie

${ }^{4}$ T. Paleczny, Zabawa w czasach globalizacji, w: red. R. Kantor, T. Paleczny, M. Banaszkiewicz, Wąż w raju: Zabawa w społeczeństwie konsumpcyjnym, Kraków 2011, s. 11.

${ }^{5}$ R. Kantor, Zabawa $w$ dobie społeczeństwa konsumpcyjnego. Szkice o ludyzmie, ludyczności i powadze, a w istocie o jej braku, Kraków 2013, s. 16.

${ }_{6}$ T. Romanowska, Zabawa w kontekście kulturowym. Część I. Człowiek zabawy-od kołyski do wieku sędziwego, „Civitas et Lex”, 2018, nr 3, s. 60.

${ }^{7}$ Prace, szkice i notatki Edmunda Bojanowskiego. Inedita. T. 1, red. E. Gigilewicz, M.L. Opiela, Lublin 2016, s. 447.

${ }^{8}$ R. Kantor, Interkulturowość zabawy : obce wzory kultury zabawy i rozrywki i ich recepcja we współczesnej kulturze ludycznej Krakowa, „Relacje Międzykulturowe”, 2017, nr 1, s. 161-162. 
dorobku przeszłości we współczesnych uwarunkowaniach realizacji integralnie rozumianego procesu edukacji człowieka w pełnym kontekście jego życia i relacji w zróżnicowanym wymiarze osobowym, pokoleniowym, kulturowym, wymaga właściwego zrozumienia. „Zadaniem edukacji jest zaciekawić odmiennością, zrozumieć ją i traktować jako bodźcującą, wykazywać, że nie ma rzeczy obcej, która w pewnych warunkach nie mogłaby stać się swoją, i z drugiej strony każda rzecz swoja mogła być kiedyś obca"9. Skoro zabawa i kultura są tak ze sobą powiązane, a zabawy i gry od zawsze stanowią formę aktywności ułatwiającej kontakty międzyosobowe i międzykulturowe, należy w adekwatny sposób wykorzystać je w edukacji.

Zagadnienie gier i zabaw w różnych kontekstach aktualnych systemów społeczno-kulturowych podejmowano od starożytności (np. Platon, Arystoteles). Rozwój filozofii i psychologii umożliwił coraz bardziej interdyscyplinarną refleksję nad edukacją z uwzględnieniem istoty i znaczenia jej wczesnego etapu. Dzięki temu zaczęto zajmować się także znaczeniem gier i zabaw w życiu, rozwoju, edukacji i zachowaniu człowieka. Tematyką tą zajmują się psycholodzy, pedagodzy, socjolodzy, historycy, językoznawcy, etnografowie. Badają i analizują powstanie, istotę poszczególnych gier i zabaw oraz ich stosowanie w danym kontekście historycznym i społecznym. Dostrzegają w nich ważny składnik życia i zachowania człowieka w kulturowych uwarunkowaniach danej epoki. Kulturologiczne ujęcie zabawy „akcentuje tworzenie się wspólnot zabawowych opartych na więziach bezpośrednich; zabawa jest powtarzalnym, wspólnotowym, autotelicznym zachowaniem się ludzi w konwencjonalnej przestrzeni i umownym czasie"10. Przyczynia się zatem do kształtowania umiejętności i sprawności we wszystkich obszarach rozwoju osoby, co ma ważny wymiar kulturowy i społeczny związany z odpowiedzialną troską o dobro wspólne.

W osobowym wymiarze i odniesieniu do różnych definicji oraz ujęć istoty i form zabawy podkreśla się, że „jest naturalną potrzebą człowieka, wprowadza nowe wartości i jest dopełnieniem naszego istnienia, rodzajem świętowania. Cechuje ją wielość form. Podejmuje się ją z własnej woli i dla przyjemności. Jest czynnością wykonywaną ze względu na indywidualne upodobania"”l. To daje teoretyczne uzasadnienie zastosowania gier i zabaw w edukacji i budowaniu relacji w kontekście kulturowym, gdyż „obecność zabawy w zachowaniach ludzi wiele mówi o źródłach kultury, tworzeniu się osobowości, funkcjonowaniu interakcji, a nawet o naturze człowieka" ${ }^{\prime 2}$.

${ }^{9}$ J. Nikitorowicz, Pogranicze, tożsamość, edukacja międzykulturowa, Białystok 1995, s. 125.

${ }_{10}$ Zabawa, w: Encyklopedia PWN, online: https://encyklopedia.pwn.pl/haslo/zabawa;3999635. html [dostęp: 22 kwietnia 2020].

${ }^{11}$ J. Truskolaska, Osoba i zabawa, Lublin 2007, s. 67.

${ }_{12}$ M. Golka, Pojmowanie zabawy, w: Karnawalizacja. Tendencje ludyczne w kulturze współczesnej, red. J. Grad, H. Mamzer, Poznań 2004, s. 12. 
Uwzględnienie społecznego i historycznego wymiaru w analizie gier i zabaw jako elementu kultury oraz ich praktyczne zastosowanie od wieków przenika poszukiwania wielu badaczy i praktyków zaangażowanych w działania edukacyjne, kulturalne i społeczne. Były one ukierunkowane na wymiar natury, kultury, religii i historii. Dał tego przykład Bojanowski, który w opracowaniu koncepcji ochrony podejmował analizy dziejów i dorobku ludzkości dla ukazania istoty ponadczasowych prawidłowości wpisanych w naturę i kulturę człowieka i ludzkości ${ }^{13}$.

Podejście Bojanowskiego i styl całościowego ujmowania rzeczywistości obrazuje podjęta za A. Mickiewiczem analiza dziejów. Na tej podstawie formułował wnioski uzasadniające potrzebny aktualnie styl i formy działań w kontekstach analogii stanowisk:

„Ludzkość przebyła epokę starożytności (zmysłową zewnętrzną), przebyła epokę średnich i nowych wieków (wewnętrzną). Teraz zadaniem epoki naszej jest harmonijne połączenie tamtych, organiczność, żywotność, zastosowanie. Będzie to niejakim zwrotem do starożytności, ale bez utracenia zdobytego kierunku wewnętrznego. Życie ludu, zastosowawszy wszystkie cechy najmłodszej ludzkości, rozwinęło się przecież pod wpływem chrześcijaństwa następnych epok. Tam już to połączenie zaczęte. Pierwotne to zaś życie ludowe nigdzie indziej nie jest tak bujne jak w młodocianym szczepie słowiańskim. Tu więc zacząć się musi odrodzenie ludzkości. Jakoż w słowiańszczyźnie widzimy nieraz sprawdzone i w życie już wprowadzone teorie Zachodu - przede wszystkim w życiu rodzinnym, domowym, w obrębie pierwotnego wychowania"14.

Tak rozumiany kontekst aktualnych potrzeb proces integralnego rozwoju oraz wychowania całego i każdego człowieka w pełnym kontekście społecznym i kulturowym, narodu i ludzkości, Bojanowski uczynił podstawą swych poszukiwań. Proces ten obejmuje całość i wszystkie wymiary życia człowieka (kulturowy, społeczny, intelektualny, religijno-moralny, estetyczny, emocjonalny, fizyczny), prowadząc do jego harmonii w wymiarze łaski, rozumu i woli. Uniwersalizm tego ujęcia wynika z katolickiej tożsamości jego myśli pedagogicznej.

Bojanowski brał pod uwagę specyfikę danej epoki, która warunkowała podejście m.in. do rozumienia i zastosowania gier i zabaw. Starożytność ceniła kulturę ciała, a stąd i zabawę. Inaczej było w średniowieczu, kiedy uznawano ją za przeszkodę na drodze doskonalenia religijnego, a w czasach nowożytnych eksponowano rozum. Kolejność epok analogicznie ukazywała etapy rozwoju człowieka. Chociaż każdy wymiar (natury, rozumu i ducha) jest bardzo ważny, to jednak każdy $z$ nich jest tylko jednym $z$ aspektów życia, rozwoju i działania osoby. Koncentrowanie w epoce starożytności na naturze służyło zewnętrzne-

${ }^{13}$ Kompendium edukacyjne Edmunda Bojanowskiego, red. M.L. Opiela, Lublin 2016, s. 19.

14 Prace, szkice ..., red. E. Gigilewicz, M.L. Opiela, s. 237-238. 
mu, fizycznemu kształtowaniu poprzez gimnastykę, ćwiczenie ciała, zmysłów, wyobraźni, uwagi, pamięci, rozumu z wykorzystaniem zabaw.

Dostrzegając „wspólność gier i zabaw starożytnych z europejskimi ludami”', Bojanowski poszukiwał właściwego ich wykorzystania w ochronkach i środowisku, by było jak najlepszym „,zastosowaniem do miejscowych potrzeb naszego kraju, ale nawet ogólnym jej postępem, który najpierw jedynie u nas objawić się może. [...] Przeto we względzie estetycznego kształcenia ludzkości, a przede wszystkim względzie pierwotnego wychowania, wypada nam uczynić niejako zwrot do starożytnego świata, nie wyzuwając się bynajmniej spod wpływu nowożytnych żywiołów - co osiągamy przez zastosowanie naturalnych pierwiastków ludu. Życie natury należy nam podnieść ku nam i takowe uszlachetnić, a nasze naturalniejszym uczynić"16.

Służyło to odejściu od zredukowanego rozumienia rzeczywistości człowieka dla jego pełnego rozwoju zgodnie z naturą, wykorzystania wytworów jego rozumu i woli dla doskonalenia duchowego. W takim podejściu można poznawać oraz wykorzystywać bogactwo dorobku kultury i cywilizacji z szacunkiem dla każdego człowieka i społeczeństwa oraz jego wytworów w integralnym rozwoju i edukacji kolejnych pokoleń.

Jest to ważne wskazanie dla współczesnego, często zredukowanego podejścia do wychowania, czy - szerzej - edukacji wynikającej z dużego stopnia specjalizacji naukowców i przekładania takich teorii na praktykę pedagogiczną. Wiąże się to $\mathrm{z}$ oderwaniem od pełnego kontekstu antropologicznego, historycznego, społecznego, kulturowego. W imię innowacyjności i postępu następuje koncentrowanie się na jakimś jednym, nawet bardzo ważnym aspekcie rozwoju i edukacji człowieka. Nie jest to jednak ujęcie integralne, czyli zapewniające całościowy rozwój osoby na każdym etapie i w pełnym kontekście społeczno-kulturowym jej życia i działania.

\section{Znaczenie gier i zabaw w integralnym rozwoju i edukacji osoby}

Zabawa jako element kultury zrodziła się z naturalnych potrzeb życiowych. Przejawia się w niej aktywność człowieka przez całe jego życie. Bawią się bowiem zarówno dzieci, jak i dorośli, a zabawy i gry są także płaszczyzną budowania relacji. Zabawa ma zatem duże znaczenie w przygotowaniu młodego pokolenia do życia i może być czynnikiem przekazywania z pokolenia na pokolenie pojęć i obyczajów.

\footnotetext{
15 Tamże, s. 249.

16 Tamże, s. 249-250.
} 
Psychologowie i pedagodzy, którzy od dawna podejmują badania i interpretacje fenomenu zabawy, podkreślają rolę gier i zabaw w rozwoju, życiu i działaniu człowieka (uczeniu się, pracy, działalności społecznej). Szczególne znaczenie mają zabawy w dzieciństwie i młodości, gdyż ich skutki widać przede wszystkim w dorosłym życiu osoby. Zabawa bowiem odgrywa szczególną rolę we wczesnej edukacji dziecka, rozumianej jako proces budowania fundamentu całego jego życia i doskonalenia osobowego. Jest podstawową formą aktywności dziecka i poznawania rzeczywistości, wpływa na rozwój procesów poznawczych, emocjonalnych oraz społecznych. Kształtuje osobowość dziecka, budzi i rozwija jego stosunek do coraz szerszego otoczenia społecznego, przyczynia się również do rozwoju sprawności fizycznej.

Bojanowski podkreślał, iż „gra i zabawa dzieci jest ich pracą, ponieważ zatrudnia ich zmysły i wyobraźnię; jest nauką, ponieważ pomnaża i doskonali ich wyobrażenia"17. W zabawach jako środku wychowania dziecięcego wyodrębnił igraszki, gry i tańce. Odróżniał zabawę od gry, która po igraszce jest jej wyższym stopniem, wyjaśniając że: „wszystkie prawie zabawy odznaczają się tym od gier, że potrzebują narzędzi, czyli pobudki zewnętrznej. W zabawach są nagrody, jako rzecz wyjątkowa u młodszych, gdy kto zadanie spełni. W grach są kary, tj. fanty jako rzecz wyjątkowa u starszych, gdy kto zadania nie spełni. W tańcach sama rzecz przez się nagradza się bez kar lub nagród"18.

Wskazał na różnicę, że „w zabawach dzieci, nie ma tu jeszcze węzła i współzawodnictwa, jakie w grach widzimy"19. Huizinga jedną definicją obejmował zabawy oparte na przedstawianiu rzeczywistości i naśladownictwie, a także gry będące współzawodnictwem, walką o coś. Jednak nie każde przedstawienie i nie każda rywalizacja jest zabawą ${ }^{20}$.

Pedagodzy wskazują, że „zabawa jako jedna $\mathrm{z}$ form poznawania świata przez dziecko odgrywa istotną rolę w jego rozwoju (fizycznym, umysłowym, emocjonalnym i społecznym), ta forma aktywności jest bowiem przez badaczy uważana za wszechstronną i zastępującą dzieciom różne czynności wykonywane przez ludzi dorosłych, tj.: uczenie się, pracę i działalność społeczną"21.

Teoretycy zabawy od zawsze przyznawali zabawom dzieci ogromne znaczenie w nabywaniu umiejętności społecznych, a jej aspekty społeczno-kulturowe $\mathrm{z}$ czasem stały się istotnym elementem wielu teorii zabawy. Dziecko podczas zabawy uczy się, tworzy, rozwiązuje problemy i trudności, co służy przygotowaniu do lepszego funkcjonowania w otaczającej rzeczywistości i zrozumieniu

${ }_{17}$ Prace, szkice..., red. E. Gigilewicz, M.L. Opiela, s. 454.

${ }^{18}$ Kompendium..., red. M.L. Opiela, s. 189.

19 Tamże, s. 204.

${ }^{20}$ J. Huizinga, Homo ludens..., s. 89-115.

${ }^{21}$ B. Muchacka, Zabawa w poznawczym rozwoju dziecka, „Pedagogika Przedszkolna i Wczesnoszkolna" 2014, nr 3, s. 7. 
różnych zjawisk, mechanizmów w niej zachodzących ${ }^{22}$. Są przywoływane jako istotne mechanizmy uspołeczniania dziecka czy przejawy społecznego funkcjonowania człowieka dorosłego.

Środki wychowania dziecięcego Bojanowski analizował w odniesieniu kolejnych epok, wskazując że pełne ujęcie znajdują one w dopełniających się żywiołach ludowych: zabaw, zbudowań i zatrudnień. Opisowi tych środków, dobieraniu ich do odpowiednich zajęć w procesie kształtowania pożądanych postaw, zachowań, umiejętności i sprawności dzieci, w zależności od wieku i indywidualnych skłonności, poświęcił najwięcej miejsca w opracowaniu zbioru wskazań ${ }^{23}$. Poprzez naśladowanie w zabawie różnych czynności, ról życiowych, płciowych i społecznych dziecko powoli wchodzi w świat ludzi dorosłych.

Dla harmonijnego rozwoju dziecka potrzebne są różne formy zabawy - od najprostszych igraszek po złożone gry, odpowiednio do jego potrzeb i możliwości. Uwzględniał to Bojanowski, opisując stopnie rozwoju poszczególnych sprawności i umiejętności z zastosowaniem odpowiednich rodzajów zabaw. Podzielił je więc i ułożył w kolejności tak, że „najniższe nie mają żadnego zadania prócz uciechy igrania $\mathrm{z}$ narzędziem, które daje pochop do zabawy, po większej części samotnie, pojedynczo wykonywane być mogą, gdyż każdy pojedynczy wystarcza wszystkim warunkom zabawy i wszystkie prawie wymagają, narzędzi aparatów czyli zewnętrznej pomocy, zabawki"24. Wyróżnił zatem:

1. Igraszki dla ćwiczenia ciała - nóg, rąk, wszystkich części ciała; zmysłów

- wzrok, słuch, dotyk; wyobraźni - piasek, cacka, dowolne ćwiczenia.

2. Gry ćwiczą: baczność, pamięć, rozum.

3. Tańce: pląsy, tańce, pochody ${ }^{25}$.

Dla wszystkich wyróżnionych gier i zabaw dobrał konkretne ich rodzaje i przykłady, opisane w literaturze, zebrane od ludu i z własnych doświadczeń, proponując zabawki, miejsce (w sali, na świeżym powietrzu), podzielił zabawy na te dla dziewcząt i dla chłopców ${ }^{26}$. Wpisał je w planowany odpowiednio do pór roku, roku kalendarzowego i liturgicznego trzyletni cykl rozkładu zajęć dla dzieci ${ }^{27}$. W tym ogólnym planie ujął zabawy w kontekście pozostałych środków zbudowań i zatrudnień. Uzasadniał to, sięgając do społeczno-kulturowego i dziejowego kontekstu swych analiz:

${ }^{22}$ E. Kurowicka, Zabawa dziecka $w$ wieku przedszkolnym w koncepcji pedagogicznej bł. Edmunda Bojanowskiego, „Roczniki Pedagogiczne” 2017, nr 9, s. 213.

${ }^{23}$ Kompendium..., red. M.L. Opiela, s. 20.

${ }_{24}$ Tamże, s. 189.

${ }^{25}$ Tamże, s. 188-189.

${ }^{26}$ Prace, szkice..., red. E. Gigilewicz, M.L. Opiela, s. 443-558.

27 Tamże, s. 369-441. 
„Wszelka całej ludzkości działalność odbywa się w świecie fizycznym, duchowym i społecznym, zatem i w pierwotnym wychowaniu dziecięcym pojawiać się już winny te same strony kształcenia (fizycznego, moralnego i społecznego), które wszakże na niniejszym poziomie dziecięcego stanowiska przybrać mogą tylko skromny charakter:

a) zabaw (igraszki, gry, tańce) - ku gimnastycznemu ćwiczeniu ich ciała i umysłu,

b) zbudowań (powiastki, pieśni i obrządki światowe. pobożne, domowe) ku napawaniu ich mlekiem duchowym,

c) zatrudnień (roboty, przodownictwo, uroczystości) - ku sposobieniu ich do pracy, nauki i życia społecznego" 28 .

Takie kształtowanie osobowości i rozwijanie samodzielności dziecka, wprowadzanie go w relacje społeczne, odpowiedzialne działania z innymi i dla innych w nauce, pracy, świętowaniu, dla doskonalenia siebie i służby innym, dokonuje się skutecznie z udziałem dorosłych. Wszystkie te relacje i działania służyły wzajemnej wymianie wartości w wymiarze międzypokoleniowym uczestników, z udziałem właściwym dla wieku etapie edukacji i doskonalenia osobowego każdego z nich. Za Platonem określił wpływ zabawy na przyszłe życie człowieka: „Całe dalsze kształcenie człowieka spoczywa na takim wychowaniu, które dziecięciu w jego niewinnej igraszce umie już wzniecić jego zamiłowanie ku temu, co w późniejszym życiu potrzebnym mu będzie, by w swoim powołaniu dzielnie się wyzwolił"29.

W koncepcji pedagogicznej Bojanowskiego ważne jest organizowanie dzieciom zabaw dla realizacji celów wychowawczo-dydaktycznych. Zbiór szczegółowych opisów zabaw, gier i igraszek zawarty w krytycznej edycji jego notatek może służyć do zastosowania ich w różnych formach aktywności poznawczej i rozrywkowej dzieci, młodzieży, dorosłych ${ }^{30}$. Analiza tych treści może być inspiracją i źródłem wskazań dla dowartościowania i właściwego wykorzystania zabawy w integralnym rozwoju i edukacji osoby dzisiaj.

\section{Walor aplikacyjny gier i zabaw w integracji międzypokoleniowej i międzykulturowej}

Znaczenie kulturotwórczej funkcji gier i zabaw, uzasadnione interdyscyplinarnymi badaniami, potwierdza praktyka edukacyjna i społeczno-kulturalna właściwa dla specyfiki miejsca i czasu. Podkreślana jest wartość ich wykorzy-

${ }^{28}$ Kompendium..., red. M.L. Opiela, s. 166-168.

${ }_{29}$ Prace, szkice..., red. E. Gigilewicz, M.L. Opiela, s. 276.

30 E. Kurowicka, Zabawa dziecka..., s. 210-213. 
stania w kształtowaniu aktywności komunikacyjnej dla wzajemnej wymiany komunikatów językowych i niejęzykowych oraz podjęcia interakcji i działań między pokoleniami. Chodzi o integrację oraz wzajemne ubogacenie się, by skutecznie włączać w działania, wykorzystując różne potencjały grup pokoleniowych. Efekty integracji międzypokoleniowej są najlepsze, gdy układa się ona po linii relacji właściwych dla rodziny wielopokoleniowej, w której dzieci, rodzice i dziadkowie $\mathrm{z}$ wzajemnym szacunkiem realizują właściwe sobie role i zadania życiowe.

Przekaz wartości na tej płaszczyźnie integracji uzasadnia znaczenie kulturowego kontekstu zabawy:

„Bawiące się dziecko «zatopione» jest we wspólnocie kulturowej przez powtarzane pokoleniowo zabawy, rodzaj zabawek im oferowanych przez konkretne społeczeństwo (rodziców), a nade wszystko przez język. Następuje w niej (i dzięki niej) swoiste przecieranie się dziecka przez ogromną różnorodność komunikatów językowych, ruchowych, moralnych, estetycznych realizowanych w różnych kodach kulturowych. Jest ono konieczne, bowiem brak rozeznania w nich utrudnia zabawę, utrudnia życie. Nie dyskredytując żadnego z kodów, lecz rozpoznając je można na tej podstawie rozwijać zachowania tolerancyjne, zachowania szanujące inność własną i drugich ludzi. Jest to też podstawą do poszukiwania kodu wspólnego bawiących się ludzi. Każdy rodzaj zabawy takich możliwości dostarcza"31.

Dla wszystkich uczestników, bez względu na wiek, lecz ze względu na właściwe im role życiowe, zabawa stanowi ważny element życia, relacji, działania i rozwoju, sprzyjający wzajemnej integracji.

Zabawy wykorzystywane są również do wzbudzenia potrzeby i rozwijania wzajemnych relacji między społecznościami odmiennymi kulturowo. W czasach globalizacji może to skutecznie prowadzić do budowania jedności w różnorodności z zachowaniem dziedzictwa i tożsamości oraz doświadczenia bogactwa dorobku ludzkiej myśli i twórczości. Zabawy i gry mają tu bardziej uniwersalny charakter niż np. literatura, obrzędowość i zwyczaje, które w nich znajdują wyraz. Zarówno międzypokoleniowa, jak i międzykulturowa integracja osób i społeczności może rozpoczynać się w zabawie dla nawiązania relacji, przekazu i wymiany wartości osobowych i kulturowych.

Obydwa wymiary integracji były dla Bojanowskiego ważne, by skarby narodowej kultury służyły edukacji przez kultywowanie tradycji oraz integracji w rodzinie i środowisku. Świadomy znaczenia dorobku przeszłości w kształtowaniu teraźniejszości, starał się teoretycznie określić i uzasadnić działania wychowawcze skierowane do małych dzieci, kobiet i ludu w ochronach. Nadając

${ }^{31}$ D. Waloszek, Kulturowy kontekst zabawy, online: http://encyklopediadziecinstwa.pl/index.php/ Kulturowy_kontekst_zabawy [dostęp: 16 kwietnia 2020]. 
im znaczenie $\mathrm{w}$ wymiarze praktycznym i symbolicznym, sięgał do literatury, kultury, historii i religii. Odwołując się do tezy M. A. Julliena, że różnice między ludźmi w dużej mierze pochodzą $\mathrm{z}$ różnic $\mathrm{w}$ ich wychowaniu, wyraził przekonanie, że „przez dzieci tylko można odrodzićludzi; wychowanie i nauka podają do tego środki, a pierwiastkowe wodze dziecięcia w rękach biegłych stają się węzłem rządu" 32 i dążył do jego realizacji. Chodziło o wychowanie mądrych i odpowiedzialnych obywateli, zdolnych do spełnienia ważnych zadań oraz poradzenia sobie $\mathrm{z}$ wyzwaniami, ustawicznie postępując $\mathrm{w}$ dążeniu do pełni człowieczeństwa.

Bojanowski był przekonany, że odnowę i zachowanie ducha narodowego można uskutecznić jedynie przez przekazywanie go następnym pokoleniom, począwszy od dzieci w rodzinie i środowisku. „One zarówno z ludem, nie oddalając się jeszcze od strzechy domowej, ani nie obracając się jeszcze pomiędzy obcymi narodowościami, powinny się rozwijać pod wyłącznym wpływem swojskich i jedynie im zrozumiałych żywiołów narodowych" ${ }^{33}$. Nie chodziło o izolowanie się, lecz odkrywanie własnej tożsamości (narodowej, słowiańskiej) i świadome jej rozwijanie, by z szacunkiem dla innych narodów dzielić się dobrem. „Te zaś rodzinne żywioły słowiańskie mogą się swym ożywiającym wpływem pierwotnego wychowania rozlać na resztę ucywilizowanego świata"34. Stąd tak ważny jest pełny rozwój osoby dokonujący się w całożyciowym procesie usprawniania ciała, zmysłów i umysłu. Temu może służyć aplikacja dorobku kultury, w tym gier i zabaw. Dla realizacji tego procesu w rodzinie i wspierających ją formach edukacji, regionu, narodu i międzynarodowym podjęto już analizy i opracowanie właściwej temu pedagogii ${ }^{35}$.

Zakładając ochrony, Bojanowski określił metody i środki wychowania dziecięcego w odniesieniu do zdiagnozowanej przez siebie aktualnej sytuacji wychowania dzieci w kontekście dorobku ludzkości. Wskazał też na konieczność jej odnawiania przez powrót do źródeł. Uzasadniał to następująco: „nowy ten kierunek wychowania wypływa z kierunku wiedzy słowiańskiej - gdzie te wszystkie żywioły pierwotne, ludowe są dotąd jeszcze dziewicze i obfite"36. Opracowana przez niego metoda i metodyka wykorzystania zebranych zabaw, gier, opowiadań, przysłów, poezji, pieśni, tańców, obrzędów, po uwspółcześnieniu ich opisów i treści, może ubogacić współczesne działania metodyczne w placówkach oświatowych, opiekuńczo-wychowawczych, grupach formacyjnych, ośrodkach wsparcia i integracji społecznej. Ich odniesienie do przeszłości, związek z naturą,

32 Kompendium..., red. M.L. Opiela, s. 109.

33 Tamże, s. 39.

34 Tamże, s. 40

35 M. Opiela, Osoba i rodzina wobec wyzwań cywilizacyjnych. Pedagogia integralnego rozwoju $i$ edukacji w koncepcji ochrony Edmunda Bojanowskiego, Lublin 2019.

36 Prace, szkice..., red. E. Gigilewicz, M.L. Opiela, s. 369-370. 
prostota środków i obrzędowy charakter są otwarte na integrację i budowanie wspólnoty w wymiarze międzypokoleniowym i międzykulturowym ${ }^{37}$.

Pedagogia ta, realizowana w szerokim kontekście relacji społecznych, miała służyć także przekazowi dorobku kolejnych pokoleń dzieci. Pisał:

„Twórczość dzieci podsycana właściwymi żywiołami - będzie i nadal czynną, a to wyrabianie sobie coraz nowych igraszek pod wpływem harmonijnego działania na nich środków wyborowych i coraz czystszych wpływów - będzie nie tylko ważnym nader rozwijaniem się ich ze samych siebie, ale nadto, pomnażać się będzie skład przerobionych już w duchu dziecięcym środków, które coraz skuteczniej przelewać się będą na upłodnienie przyszłych pokoleń dziecięcych"38.

Było to skuteczne w kontekście przekazu wartości i skarbów kultury przez starsze pokolenia.

Bojanowski sięgał zatem do dziejów ludzkości i narodu, jego tradycji i kultury, by -zachowując dorobek przeszłości - dobrze rozumieć potrzeby i problemy współczesności i odpowiedzialnie budować przyszłość. Wyrosła z potrzeb społecznych idea ochrony, rozumiana jako czynność i jako instytucja, wyrażała dążenia epoki i była miejscem, w którym ludzie mogli służyć sobie nawzajem pomocą, dobrami kultury i osobistych darów, pracą dla dobra wspólnego. Ta wzajemność zależności i wymiany wartości jest jednym z głównych założeń Bojanowskiego. Służyła realizacji dążeń do braterstwa ludów, unii i harmonii, a wzajemna dopełniająca się wymiana miała dokonywać się między żywiołami świata i ducha, między Zachodem Europy i Wschodem - słowiańszczyzną, między warstwami wyższymi i ludem, między młodością i starością, miastem i wioską. Tak człowiek mógł się rozwijać zgodnie ze swą tożsamością, z uwzględnieniem swoistego charakteru każdego ludu, narodu, kultury, pokolenia, osoby, wieku itd.

Przemiany cywilizacyjne, a z nimi związane zmiany w sferze obyczajowej, spowodowały załamanie relacji międzypokoleniowych w rozumieniu tradycyjnym. Obecnie wyzwaniem jest rozwijanie przestrzeni i form aktywności prowadzących do kontaktów międzypokoleniowych, także poza rodziną. Podejmowanie takich działań wiąże się z potrzebą budowania spójnych i zintegrowanych społeczności lokalnych, a perspektywa międzypokoleniowa jest włączana do programów ich integracji.

W życiu, edukacji i budowaniu relacji międzyosobowych w każdym środowisku kulturowym, niezależnie od kraju czy kontynentu, ważny jest międzypokoleniowy przekaz cywilizacyjnych zdobyczy. Otwierając się na inne środowiska kulturowe i szanując swą tożsamość, można nawzajem poznawać ich dorobek i ubogacać się nim. Pozwala to na ich twórczą aplikację w procesie kontynuacji

${ }^{37}$ M. Opiela, Osoba i rodzina wobec wyzwań..., s. 191.

${ }^{38}$ Kompendium.., red. M.L. Opiela, s. 166. 
oraz kreatywnej modyfikacji i nawiązania do dorobku pokoleń przez dopasowanie form do aktualnych warunków.

Znaczenie i skuteczność aplikacji gier i zabaw potwierdzają doświadczenia Sióstr Służebniczek z praktyki edukacyjnej i społecznej realizowanej według koncepcji E. Bojanowskiego w różnych formach i krajach Europy, Afryki, Ameryki Południowej i Północnej. Wykorzystywanie jego spuścizny przekracza różnice czasu, wyznania, kultury, bo w centrum wskazań stoi osoba, szacunek dla godności i prawidłowości jej rozwoju zgodnie z naturą. Służy edukacji osoby przez całe życie, pozostawiając jej możliwość wyboru zachowań w granicach danego wzorca kulturowego. Gry i zabawy wpisane w rodzime tradycje i zwyczaje wprowadzają uczestników do wspólnego świętowania, wyrażają piękno kultury, bogactwa historii i tradycji ojczystej. Tak budowane relacje łączą pokolenia, osoby różnych kultur i wyznania, tworząc płaszczyznę spotkania, wzajemnego wsparcia i dojrzewania osobowego.

Dzięki możliwości zapoznania się z obcymi wzorami kultury zabawy i rozrywki, jako rodzajem kontaktów między ludźmi, wyrazem potrzeby wspólnego działania i przeżywania, można te wzory skonfrontować $\mathrm{z}$ własnymi. Można je przyjąć bądź odrzucić, dostosować do własnych potrzeb, dokonując w ramach tej adaptacji zmian i przekształceńn ${ }^{39}$. Ważne jest, by w spotkaniu ludzi różnych kultur dokonywało się to we wzajemnej wymianie i ubogaceniu. Zabawy i gry mają charakter uniwersalny, bo bawią się wszyscy ludzie, jest to naturalna potrzeba, ale bawią się różnie, bo wychowali się w konkretnej kulturze i mogą wzajemnie ubogacać się różnorodnością.

Współcześnie podkreśla się znaczenie gier jako narzędzia w procesie edukacji, które przynosi konkretną korzyść jednostce, a w szerszym znaczeniu - organizacji i gospodarce ${ }^{40}$. Teoretycznie i praktycznie wskazuje się na obopólne korzyści zabawy. W literaturze dla nauczycieli proponuje się wykorzystanie gier i zabaw w nauczaniu obcokrajowców polskiej grzeczności językowej. Służą one kształceniu sprawności językowych, rozwijaniu zasobu słownictwa, przybliżaniu kontekstów kulturowych, wprowadzając jednocześnie do sformalizowanego procesu kształcenia elementy swobody i aktywności twórczej $\mathrm{w}$ komunikowaniu interpersonalnym oraz interpersonalno-medialnym ${ }^{41}$. Ma to dużą rolę w nauczaniu obcokrajowców polskiego języka i w relacjach z nimi (np. wychowawczych), by uwzględniać specyfikę wynikającą z wielorakich różnic społecznych czy kulturowych.

${ }^{39}$ R. Kantor, Interkulturowość zabawy..., s. 163-164.

${ }^{40}$ G. Leśniewska, Gry jako narzędzia wspierające proces edukacji, „Studia i Prace WNEIZ US” 2017, nr 1, s. 65-75.

${ }^{41}$ L. Sikorska, Gry i zabawy petnią istotna funkcję w nauczaniu obcokrajowców polskiej grzeczności językowej, "Języki Obce w Szkole” 2017, nr 3, s. 97. 
Znaczenie aplikacji gier i zabaw w edukacji oraz budowaniu relacji potwierdza zainteresowanie teoretycznym i praktycznym zastosowaniem tej koncepcji w odległym czasie od jej powstania i terenie jej realizacji współcześnie. W 170 lat od założenia Zgromadzenia Służebniczek przez E. Bojanowskiego (3 maja 1850 r.) prowadzone są badania i działania aplikacyjne na podstawie krytycznej edycji jego notatek. Zawarł w nich m.in. analizy kulturotwórczego potencjału gier i zabaw oraz ich ponadczasowego charakteru w ujęciu teoretycznym i historycznym. Opracowany na podstawie tych pism program wychowania przedszkolnego, na życzenie Sióstr realizujących go w różnych krajach świata, został ostatnio przetłumaczony na język angielski, a wcześniej na hiszpański i francuski. Służy temu dynamiczny charakter koncepcji, gdyż - mimo upływu czasu - pozostaje ona wciąż w stanie tworzenia, zachowując swą tożsamość dzięki dokonywaniu jej aktualizacji w aspekcie ciągłości i zmiany.

\section{Podsumowanie}

Bojanowski sięgał do dziejów ludzkości i narodu, jego tradycji i kultury, by zachowując dorobek przeszłości - dobrze rozumieć potrzeby i problemy współczesności oraz odpowiedzialnie budować przyszłość. Ochrona jako instytucja odgrywała tu ogromną rolę jako miejsce spotkania, wychowania najmłodszych i oświaty ludu. Bojanowski stworzył konkretną koncepcję oraz styl jej realizacji, by odpowiadała na aktualne potrzeby i problemy człowieka, którego natura ma swoje prawa i nie zmienia się, natomiast kultura oraz dorobek ludzkości, rozwijając się, tworzą nowe uwarunkowania ich zaspokojenia. Wobec współczesnych wyzwań cywilizacyjnych edukacja może i powinna umożliwić twórczy powrót do tego, co podstawowe w wychowaniu, integracji międzypokoleniowej i międzykulturowej, sprawdzonych i wartościowych, służących budowaniu na mocnym fundamencie wartości i tradycji, a odpowiadających realnej rzeczywistości indywidualnej i społecznej.

Aplikacja gier i zabaw w integracji międzypokoleniowej i międzykulturowej według koncepcji Bojanowskiego stanowi społeczno-kulturowy walor, który można dziś z powodzeniem zastosować. Zabawa, która jest uznana za osnowę kultury, wypływającą z samej istoty społeczeństwa, może stać się ważnym dynamizmem integralnego rozwoju człowieka i cywilizacji.

\section{Bibliografia}

Gigilewicz E., Opiela M. L. (red.), Prace, szkice i notatki Edmunda Bojanowskiego. Inedita, T. 1, Lublin 2016. 
Golka M., Pojmowanie zabawy, w: Karnawalizacja. Tendencje ludyczne w kulturze współczesnej, red. J. Grad i H. Mamzer, Poznań 2004, s. 12.

Huizinga J., Homo ludens. Zabawa jako źródło kultury, Warszawa 1985.

Kantor R., Zabawa w dobie społeczeństwa konsumpcyjnego. Szkice o ludyzmie, ludyczności i powadze, a w istocie o jej braku, Kraków 2013.

Kantor R., Interkulturowość zabawy : obce wzory kultury zabawy i rozrywki i ich recepcja we współczesnej kulturze ludycznej Krakowa „,Relacje Międzykulturowe” 2017, nr 1, s. 161-195.

Kurowicka E., Zabawa dziecka w wieku przedszkolnym w koncepcji pedagogicznej bł. Edmunda Bojanowskiego, „Roczniki Pedagogiczne” 2017, nr 9 (specjalny), s. 205-215.

Leśniewska G., Gry jako narzędzia wspierające proces edukacji, "Studia i Prace WNEIZ US" 2017, nr 1, s. 65-75.

Muchacka B., Zabawa w poznawczym rozwoju dziecka „Pedagogika Przedszkolna i Wczesnoszkolna" 2014, nr 1, s. 7-18.

Nikitorowicz J., Pogranicze, tożsamość, edukacja międzykulturowa, Białystok 1995.

Opiela M.L. (red.), Kompendium edukacyjne Edmunda Bojanowskiego, Lublin 2016.

Opiela M., Osoba i rodzina wobec wyzwań cywilizacyjnych. Pedagogia integralnego rozwoju i edukacji w koncepcji ochrony Edmunda Bojanowskiego, Lublin 2019.

Paleczny T., Zabawa w czasach globalizacji, w: Wąż w raju: Zabawa w społeczeństwie konsumpcyjnym, red. R. Kantor, T. Paleczny, M. Banaszkiewicz, Kraków 2011, s. 9-29.

Romanowska T., Zabawa w kontekście kulturowym, „Civitas et Lex", 2018, nr 3, s. 47-76.

Sikorska L., Gry i zabawy pełniq istotna funkcję w nauczaniu obcokrajowców polskiej grzeczności językowej, „Języki Obce w Szkole" 2017, nr 3, s. 97-101.

Truskolaska J., Osoba i zabawa, Lublin 2007.

Waloszek D., Kulturowy kontekst zabawy, online: http://encyklopediadziecinstwa.pl/index.php/ Kulturowy_kontekst_zabawy [dostęp: 16 kwietnia 2020 r.].

Zabawa w: Encyklopedia PWN, online: https://encyklopedia.pwn.pl/haslo/zabawa;3999635.html [dostęp: 22 kwietnia 2020 r.].

Społeczno-kulturowa wartość wykorzystania gier i zabaw w edukacji, integracji międzypokoleniowej i międzykulturowej według koncepcji Edmunda Bojanowskiego

\section{Streszczenie}

Celem artykułu jest ukazanie społeczno-kulturowego waloru aplikacji gier i zabaw na rzecz innowacji w edukacji, integracji międzypokoleniowej i międzykulturowej. Wykorzystanie koncepcji E. Bojanowskiego oparte na krytycznej edycji jego notatek w odniesieniu do interdyscyplinarnego dorobku nauk społecznych i humanistycznych posłużyło opracowaniu teoretycznych podstaw rozwiązań metodycznych. Na tej podstawie przedstawiono gry i zabawy jako element kultury dawnej i współczesnej, ich znaczenie dla integralnego rozwoju i edukacji osoby oraz społeczno-kulturowy walor ich aplikacji w integracji międzypokoleniowej i międzykulturowej. Ukazano i uzasadniono społeczno-kulturową wartość, potrzebę, zasady korzystania z dorobku przeszłości i jego aplikacji we współczesnej praktyce edukacyjnej i kulturalnej.

Słowa kluczowe: zabawa, gra, osoba, społeczność, kultura, edukacja, integracja 


\title{
Socio-cultural value of using games and plays in education, intergenerational and intercultural integration according to Edmund Bojanowski's concept
}

\begin{abstract}
Summary
The aim of the article is to show the socio-cultural value of applications of games and plays for the benefit of innovation in education, intergenerational and intercultural integration. The use of E. Bojanowski's concept based on a critical edition of his notes in relation to the interdisciplinary achievements of social sciences and humanities serves to develop the theoretical basis for methodical solutions. On this basis, games and plays are presented as an element of both old and modern culture. The article also highlights their importance for the integral development and education of a person and the socio-cultural value of their application in intergenerational and intercultural integration. The socio-cultural value, need, principles and ways of using the heritage of the past and its applications in contemporary educational and cultural practice are shown and justified.
\end{abstract}

Keywords: fun, game, person, community, culture, education, integration 